\title{
Die waarde en uitdagings van diensleer vir tolkopleiding: die ervaring van die tolkopleidingsprogram aan die Universiteit Stellenbosch
}

\author{
Harold M Lesch \\ Departement Afrikaans en Nederlands, Universiteit Stellenbosch, Suid-Afrika \\ Epos: hlesch@sun.ac.za
}

\section{Opsomming}

Die behoefte aan doeltreffende kommunikasie in 'n samelewing, saam met die taalwerklikhede van die openbare domein, noodsaak dat taaldienslewering in 'n veeltalige land 'n prominente rol speel. Gevolglik word die opleiding van professionele tolke aan ons tersiêre instellings noodsaaklik, aangesien die tolkpraktyk in 'n veeltaligheidskonteks bevorder behoort te word. Tolkopleiers beskou blootstelling aan en ondervinding in die tolkpraktyk as 'n onmisbare onderdeel van die opleidingsprogram vir beginnertolke. Hierdie artikel is 'n voorafstudie wat fokus op die interaksie met taalgemeenskappe en diensleer vanuit die perspektief van tolkopleiding. Winston (2005:223) voer aan dat "practicum, service learning, and interacting with community groups all reinforce the underlying understanding that students need $[\ldots]$ to learn through interactive, collaborative experiences with others". Hierdie aktiwiteite is "student-centered learning activities that foster the development of critical thinking, decisionmaking, and self-assessment that are essential to interpreting effectively and competently" (ibid.). Kritiese denke, etiese besluitneming en selfassessering is kernvaardighede wat studente benodig vir die tolkpraktyk. Volgens die beginsels van gesonde gemeenskapsinteraksie moet diensleer nie as 'n lukraak aktiwiteit beoefen word waar die studente vrye teuels gegee word nie, maar dit behoort ingebed te wees in 'n akademiese kursus en formeel geassesseer word. Studente behoort op so 'n wyse na te dink oor die diensleeraktiwiteit dat hulle verdere begrip van en groter waardering vir die dissipline kry, sowel as 'n verhoogde bewustheid van persoonlike eiewaarde en verantwoordelikheid teenoor die burgerlike samelewing ontwikkel (Bringle en Hatcher 1995:12). Teen hierdie agtergrond ondersoek die artikel die interaksie van die leerlingtolke met die taalgemeenskappe en die rol wat diensleer in hulle opleiding speel. Die diensleer in hierdie konteks is kursusgebaseerd en kredietdraend. Deur die tolkgebeure behoort die studente insgelyks meer kennis te bekom van en ervaring te verkry in die tolkpraktyk, maar ook in die waarde daarvan vir interkulturele kommunikasie. Die bereiking van hierdie uitkomste word beoordeel deur refleksie oor die diensleerervaring van die leerlingtolke. Die metodologie vir hierdie artikel behels 'n teoretiese verkenning van die veld, 'n kritiese ondersoek na die studente se ervaring soos deur hulleself opgeteken en laastens 'n besinning oor die gepaardgaande uitdagings.

Sleutelwoorde: tolking, opleiding, diensleer, gemeenskap 


\section{The value and challenges of service learning for interpreter training: the experience of the interpreting training programme at Stellenbosch University}

\section{Extended abstract}

The quest for effective communication in society and the language realities of the public arena, necessitate that language service delivery in a multilingual country should play a prominent role. Consequently, the training of interpreting professionals becomes indispensable in our tertiary institutions, as interpreting practice in a multilingual context needs to be encouraged. Trainers of interpreters perceive exposure to and experience in the interpreting practice as an essential part of the training programme of these novice interpreters.

This article is a preliminary study that reflects on the role of interaction with the community and service learning in interpreter training. According to Winston (2005:223) "practicum, service learning, and interacting with community groups all reinforce the underlying understanding that students need [...] to learn through interactive, collaborative experiences with others". These activities are "student-centered learning activities that foster the development of critical thinking, decision-making, and self-assessment that are essential to interpreting effectively and competently" (ibid.). Critical thinking, ethical decision making, and self-assessment are core skills for students in interpreting. According to community interaction principles, service learning should not be seen as a random activity where students have carte blanche, but it should be embedded in an academic course and formally assessed. Students should reflect on the service learning activity in such a way that they gain further understanding and broader appreciation of the discipline, and a sense of personal value and civic responsibility (Bringle and Hatcher 1995:12).

Against this backdrop, this article investigates the interaction of the trainee interpreters with the language community and the role of service learning in their training. Through the interpreting experience, students should not only be able to gain more knowledge of and appreciation for the discipline, but also the value thereof for intercultural communication. Whether these outcomes are achieved, is assessed by reflection on the service learning encounter of the trainees. The methodology of this study constitutes a theoretical investigation of the field, a critical examination of the students' experiences as documented by them, and lastly a reflection on the challenges involved.

It is envisaged that interaction with the community will contribute to an environment where student learning is enriched and research relevance is enhanced. It is argued that community interaction supports the institutional commitment to reciprocity, redress, development and transformation. This interaction can take on various shapes and forms within the context of higher education as highlighted in the article. These include, among others, community-based research, participatory action research, professional community service and service learning. In its fullest sense, community interaction is the combination and integration of teaching and learning (i.e. service learning). Different forms of community engaged learning can be identified. These forms may be placed on a continuum between two important distinctions, namely the primary beneficiaries of the service (i.e. the community or student) and the primary goal of the service (i.e. community service or learning).

Within the framework of Kolb's cycle (1984:41) for the learning experience, one is fully aware of the educational advantages service learning has for the trainee interpreter. The service 
learning component for the interpreting students entails that students should deliver an interpreting service to various linguistic communities. Within an up-and-coming multilingual country, one would assume that it would be rather easy to obtain the appropriate sites to deliver such a service, but this is easier said than done. In the Western Cape there is a great need for liaison interpreters in the healthcare setting (see Levin 2005; Schlemmer 2005; Lesch 2007:74). In accordance with the categories of service learning, as mentioned in the article, both the community (i.e. the healthcare community including the professional service provider and the patient) and the trainee interpreter would benefit from this relationship. However, there are various challenges; for instance, at one tertiary institution the healthcare management are in agreement regarding the importance of healthcare interpreting, but fall short of giving permission to accommodate the trainee interpreters at their institution. The main concerns are ethical issues, including the possibility of incorrect information being conveyed by the trainee and the confidentiality of patient information. One agrees that this is a valid concern, but in a survey conducted by Feinauer and Lesch (2009) at this very healthcare institution, it was established there was only one untrained interpreter for this major institution. The gap between theory and practice is evident - to argue in favour of political correctness, but to practice the opposite.

Kolb's concept of experiential learning (as in the case of the trainee interpreter) further explores the critical pattern of learning from experience through reflection to conceptualisation and action, returning to further experience. Concrete experience entails direct practical experience. Witter-Merithew and Johnson discovered that when students work together to reflect on their work, they "gain deeper levels of understanding" (2005:45). Reflective observation focuses on what the experience means to the individual and requires observation, examination, analysis and interpretation of a specific concrete experience. Abstract conceptualisation gives meaning to discoveries by relating them to other discoveries, other forms of knowledge; and active experimentation is taking further action and testing conceptualisations (and their implications) in different situations.

Research has shown that service learning is a powerful pedagogy and it involves expertise. For students to have the best possible gain from the exercise it should be structured to enhance student development. This cycle provides the student with the means to create a link between learning experiences, theoretical grounding of these experiences and the real world. Furthermore, it provides room for active experimentation that can transform conceptualisation, test abstraction in practice, and construct and modify the next concrete experience. According to Sax and Astin (1997), the outcomes of service learning are aimed at academic development, life skills, including racial tolerance and cultural understanding (especially in intercultural communication).

As language is often undervalued, it is important to opt for a community interaction activity involving language that demonstrates an impact on the community, but most importantly also adds value for interpreter training purposes. The students should build on their experience and, as a matter of importance, share it with their peers. The interpreting internship, in accordance with Bringle and Hatcher (1995), is credit bearing. Students are required to share their experience regarding problems, challenges, positive experiences, etc. with the group during the practical sessions. However, most importantly, it is expected of them to compile a detailed written report towards the end of the academic year. 
Apart from the legislative and institutional framework such as policies, mission statements, etc., it is important, from within the interpreting programme itself, to believe in the value of the internships and to foster the partnerships with the community. It is a primary aim to establish collaborative working relationships with different communities where intercultural communication plays an important role. The importance of a language intermediary therefore becomes important within the extended communication process. These partnerships will provide the potential for a comprehensive framework and strategy for community engagement and service learning for interpreting. However, as mentioned in the article, various challenges remain.

Much of the learning for interpreters takes place in practice where they have hands-on experiences. For students this learning occurs during their practicum where they learn experientially while interpreting under the supervision of a mentor. Apart from existing challenges, lecturers should attempt to develop service learning partnerships and opportunities for students to experience their future career first-hand. This theory, and the four learning abilities of the cycle, directly relate to how interpreting students learn as they advance. It exposes the trainee to relevant skills regarding different models of interpreting, for example the "black box" or advocacy model. From the lecturers' point of view, this service learning cycle also provides the opportunity and impetus for relevant curriculum development.

Learning through experience is an important aspect of training for all interpreters. Service learning should therefore not be done haphazardly, but trainers and mentors should understand the learning cycle and how each step works to guide students or protégés through the learning process. In doing so, the trainee will be provided with "a rich learning experience and an avenue [...] to achieve life-long skills refinement" (Bentley-Sassaman 2009:67).

Keywords: interpreting, training, service learning, community

\section{Inleiding}

Die belangrikheid van doeltreffende mondelinge kommunikasie kom duidelik na vore wanneer 'n probleem ervaar word en die betrokke tolkdiens nie van die gewenste gehalte is nie of skielik onderbreek word. Dit is nóg belangriker in 'n interkulturele konteks wanneer kommunikasie die vorm aanneem van 'n uitgebreide kommunikasie-aktiwiteit, d.w.s. wanneer daar 'n taalbemiddelaar betrokke is. Dit is ' $n$ gegewe dat taal en taalbeleid deurslaggewend was in die oorgang na 'n demokratiese Suid-Afrika. Deur die erkenning van elf amptelike tale, het die wetgewende raamwerk 'n veeltalige taalbeleid daargestel. Taalgebruikers is egter openlik skepties oor die taalbeleid en die moontlikheid om veeltaligheid werklik in die praktyk toe te pas. Benewens kwessies rakende ekonomiese haalbaarheid, is daar dikwels ook 'n gevoel dat die heersende taalbeleid bloot 'n poging is om polities korrek te wees. Volgens Lesch (2005:1617; 2004:258-262) vereis samelewingsvraagstukke en taalwerklikhede in die openbare sektor dat taaldiens ' $\mathrm{n}$ prominente rol in 'n veeltalige land speel. Uitgebreide kommunikasie met verwysing na die tolkpraktyk en die opleiding van kundiges op hierdie gebied, behoort in ons tersiêre instellings bevorder te word.

Blootstelling aan en ervaring in die beroep speel 'n belangrike rol in die opleiding van hierdie beginner-beroepslui. Hierdie artikel is 'n voorafstudie en besin oor die rol van interaksie met 
die gemeenskap en die rol van diensleer vanuit die perspektief van tolkopleiding. Volgens Winston (2005) in Bentley-Sassaman (2009:66) help "practicum, service learning, and interacting with community groups all [to] reinforce the underlying understanding that students need $[\ldots]$ to learn through interactive, collaborative experiences with others". Winston gaan voort deur te sê die voorgemelde aktiwiteite is "student-centered learning activities that foster the development of critical thinking, decision making, and self-assessment that are essential to interpreting effectively and competently" (ibid.). Ek is van mening dat kritiese denke, etiese besluitneming en selfbeoordeling noodsaaklike vaardighede is vir studente wat die tolkpraktyk betree. Volgens Bringle en Hatcher (1995:112) behels die beginsels van gesonde gemeenskapsinteraksie dat diensleer nie as 'n blindelingse aktiwiteit beskou kan word waar studente carte blanche het nie, maar dat dit in 'n akademiese kursus veranker behoort te wees en by te dra tot die akademiese krediete van so 'n kursus. Studente moet op so 'n wyse oor die diensaktiwiteit besin dat hulle 'n groter begrip van en hoër waardering vir die vakgebied verwerf, en ' $n$ sin van persoonlike waarde en burgerlike verantwoordelikheid by hulle versterk word. Benewens die funksionele taalvaardighede wat die studente verwerf met hulle gemeenskapsinteraksie, is daar ook etiese kwessies soos vertroulikheid wat ter sprake kom.

Hierdie artikel het ten doel om 'n beskrywing van tolkopleiding te gee deur: (i) die belangrikheid van diensleer in die opleiding te ondersoek; (ii) vas te stel hoe diensleer deur middel van gemeenskapsinteraksie deur die leerlingtolke beleef word en (iii) die uitdagings uit te lig wat oorbrug behoort te word.

\section{Tolkprogram van die Universiteit Stellenbosch}

Die Departement Afrikaans en Nederlands aan die Universiteit Stellenbosch (US) bied die afgelope 30 jaar ' $n$ nagraadse diploma in vertaling aan. Sedert 2005 is die bestaande program uitgebrei om ook voorsiening te maak vir die opleiding van tolke. Hierdie skuif is genoodsaak deur die taalwerklikheid in die Wes-Kaap, sowel as die toenemende behoefte aan tolke; dus het studente die opsie om te spesialiseer in vertaling of tolking, of om 'n kombinasie van vertaling en tolking te volg. Die program behels een jaar voltydse studie. Die tolkkursus is gerig op generiese tolkopleiding wat 'n teoretiese en 'n praktiese komponent insluit (met inbegrip van vaardigheidsontwikkeling, sowel as blootstelling van die leerlingtolk aan konsekutiewe en simultaantolking, insluitende fluistertolking). Die program maak voorsiening vir die volgende taalkombinasies: Afrikaans $>$ Engels, Engels $>$ Afrikaans, Engels $>$ Xhosa, Xhosa $>$ Engels, sowel as Nederlands, Frans, Duits of Mandaryns met Engels. Kundiges uit die betrokke taaldepartemente word betrek na gelang van die behoefte.

Tydens hulle opleiding word van die leerlingtolke verwag om tot 'n maksimum van 60 uur verpligte internskap te doen. Die pedagogiese rasionaal hiervan is voor die handliggend, naamlik die blootstelling van studente aan die tolkpraktyk binne 'n professionele konteks. By terugskouing op die leeraktiwiteit, word van studente verwag om na afloop van hulle internskappe ' $n$ omvattende verslag te skryf. Die voordeel van die institusionele veeltaligheid en die wetgewende beleidsraamwerk wat in plek is, is dat die Departement daarin kon slaag om verskeie vennootskappe aan te gaan.

Die internskappe van die tolkstudente het in die onlangse verlede die volgende kontekste ingesluit: hospitale, spraakpatologie, studenteliggame op kampus, studentekoshuise, lesings, omliggende plase, ens. Hierdie internskappe strook met Boyer (1990) om 'n vakleerlingskap- 
model te aanvaar ten einde die student betrokke te kry in die gemeenskap. Volgens hierdie uitgebreide siening behels "vakleerlingskap" vier oorvleuelende funksies: ontdekking van vorme van kennis, integrasie (verbande tussen vakrigtings), wisselwerking tussen teorie en praktyk, en onderrig. Voor die studente uitgeplaas word, is dit die rol van die opleiers om geleenthede vir diensleer te identifiseer en verhoudings te ontwikkel. Om studente 'n voorsmakie te gee van hulle toekomstige beroep, behoort opleiers die vermoë te hê om, soos Sawyer (2006:118) dit stel, "bring the field into the classroom and the classroom out into the field, for example through a reflective practicum".

\section{Gemeenskapsinteraksie}

Die rasionaal agter die internskappe vir tolkstudente is nie bloot dat dit veranker is in die instelling se beleid t.o.v. gemeenskapsinteraksie - d.w.s. die verwagting van akademici om 'n betekenisvolle bydrae te lewer tot die breër gemeenskap - nie, maar ook dat hierdie internskappe akademiese en pedagogiese waarde het vir die leerlingtolk.

Die feit dat interaksie van die universiteit met die gemeenskap in die onlangse verlede sterker op die voorgrond getree het, het tot gevolg dat gemeenskapsinteraksie nou as een van die Fakulteit se kernfunksies beskou word. Die doel daarvan is om verhoudings met gemeenskappe te skep, daarop te bou en hulpbronne beskikbaar te stel waardeur altwee partye kennis aktief kan ontdek en wedersyds kan leer. 'n Mens moet egter let op die onderskeid wat getref word tussen die definisie van gemeenskap in gemeenskapsinteraksie en gemeenskapstolking onderskeidelik. Laasgenoemde is 'n tolkgenre wat dikwels sinoniem gebruik word met die meer neutrale term skakeltolking. ${ }^{1}$

Die verwagting is dat interaksie met die gemeenskap sal bydra tot 'n omgewing waar die studente 'n verrykingservaring het en navorsing meer gefokus sal wees. Gemeenskapsinteraksie ondersteun die institusionele verbintenis tot wisselwerking, regstelling, ontwikkeling en transformasie. Binne die konteks van hoër onderwys kan hierdie interaksie verskillende vorme aanneem. Dit sluit onder andere in gemeenskapsgebaseerde navorsing, deelnemendeaksienavorsing, professionele gemeenskapsdiens en leer, d.i. ervaringsleer d.m.v diensleer. Volgens Hoover en Whitehead (1975:25) word ervaringsleer gedefinieer as "when a personally responsible participant cognitively, affectively, and behaviourally processes knowledge, skills, and/or attitudes in a learning situation characterized by a high level of active involvement". Diensleer, daarenteen vind plaas wanneer daar' $n$ balans is tussen leerdoelwitte en die uitkomste daarvan. Volgens Furco (1996:5) is "the intention to equally benefit the provider and the recipient of the service as well as to ensure equal focus on both the service being provided and the learning that is occurring".

In die volle omvang daarvan is gemeenskapsinteraksie die kombinasie en integrasie van onderrig en leer. Verskillende vorme van leer waarby die gemeenskap betrokke is, kan geïdentifiseer word. Die primêre begunstigdes en die betrokke primêre doelwitte kan op 'n kontinuum geplaas word met die gemeenskap (begunstigde) en diens (doelwit) as die een uiterste en die student (begunstigde) en leer (doelwit) as die ander (Higher Education Quality Committee (HEQC) 2006b:14). Die onderstaande figuur identifiseer die verskeie vorme van

\footnotetext{
${ }^{1}$ Skakeltolking staan binne die Engelse literatuur bekend as liaison interpreting en verwys na situasies waar tweerigtingtolking vereis word tydens 'n gesprek tussen twee of meer partye wat nie mekaar se taal verstaan nie en vir wie dit onmoontlik is om te kommunikeer sonder die hulp van 'n tolk.
} 
gemeenskapsbetrokkenheid van studente en plaas dit op die kontinuum, soos hierbo verduidelik.
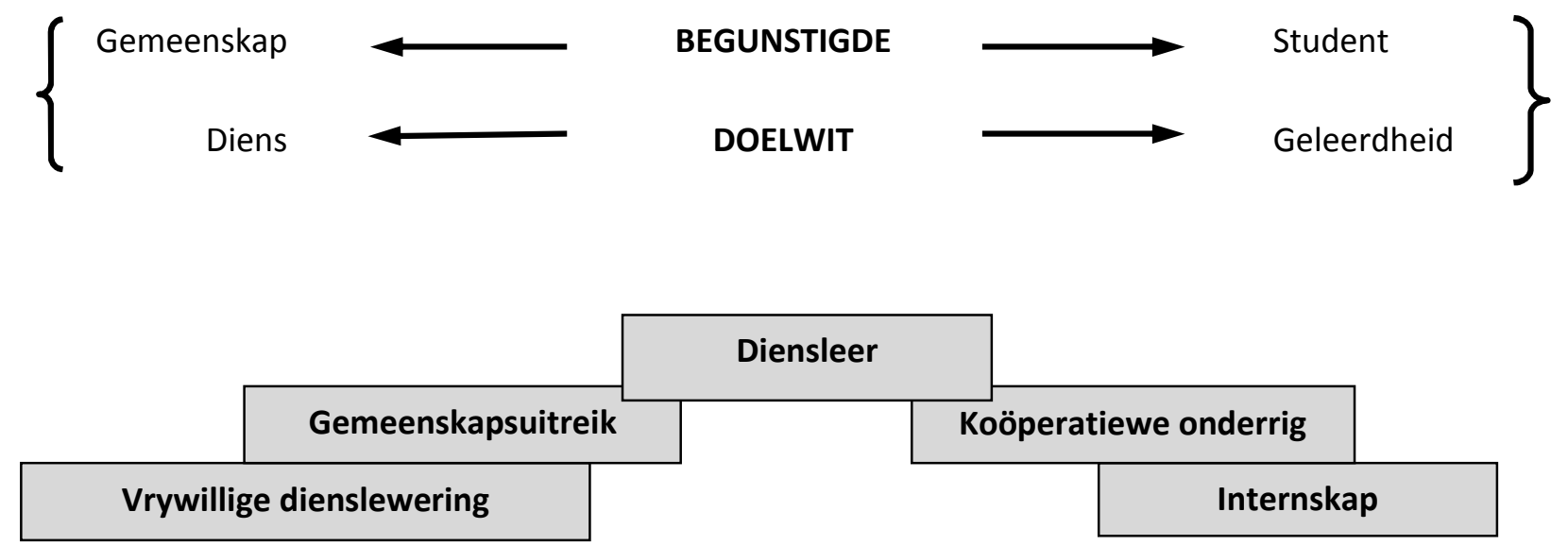

Figuur 1: Verskillende tipes leer deur interaksie met die gemeenskap (aangepas Furco (1996:4))

Die kategorieë van gemeenskapsbetrokkenheid is nie noodwendig geïsoleerd of sluit mekaar noodwendig uit nie. Elk kan soos volg verduidelik word: Vrywillige dienslewering is die een uiterste waar studente betrokke raak by aktiwiteite waar die gemeenskap die primêre begunstigde is en die primêre doel dienslewering. Volgens HEQC (2006b:14) is vrywilligerprogramme hoofsaaklik altruïsties van aard. Hoewel studente uit hierdie programme kan leer, hou dit oor die algemeen nie met die student se studieterrein verband of is daarmee geïntegreerd nie. Daarom is vrywilligerprogramme wesenlik buitekurrikulêre aktiwiteite wat buite onderrigtyd of tydens vakansies plaasvind. Die norm wat geld, is dat studente geen akademiese krediet vir deelname aan sodanige aktiwiteite kry nie.

Gemeenskapsuitreik behels ook studentebetrokkenheid by aktiwiteite waar die betrokke gemeenskap die primêre begunstigde is en dienslewering die primêre doelwit. Hierdie tipe programme is egter meer gestruktureerd en groter toegewydheid word van die studente verlang tydens die interaksie.

Die ander uiterste op hierdie kontinuum is internskappe. Laasgenoemde betrek studente by aktiwiteite waar die student die primêre begunstigde is en studenteleer die primêre doelwit. Volgens die Hoëronderwyskwaliteitskomitee (HOKK) is die doel van internskappe praktiese ervaring vir studente waardeur begrip van hulle studiegebied (tolking in hierdie geval) bevorder word, hulle leeruitkomste verwesenlik word en hulle beroepservaring opdoen (HEQC 2006b:15). Internskappe behoort ten volle in die student se kurrikulum geïntegreerd te wees.

In die geval van koöperatiewe onderrigprogramme is die student en studenteleer die primêre doelwit. Koöperatiewe onderrig voorsien die student van kokurrikulêre geleenthede wat verband hou met die kurrikulum, hoewel dit nie altyd ten volle daarin geïntegreerd is nie. Die primêre doel daarvan is om studente se begrip van hulle studiegebied te bevorder.

Diensleermodules of -kursusse betrek studente by aktiwiteite waar die gemeenskap sowel as die student primêre begunstigdes is, terwyl diens aan die gemeenskap, sowel as studenteleer 
deur lewering van hierdie diens insgelyks die doelwit is. Daarom is wisselwerking tussen die studente en die gemeenskap ' $n$ wesenlike eienskap van diensleer. Die primêre fokus van die programme is om gemeenskapsdiens met vakkundige aktiwiteite soos onderrig, navorsing en studenteleer te integreer. Hierdie vorm van gemeenskapsbetrokkenheid word ondersteun deur die aanname dat diens verryk word deur vakkundige aktiwiteite, en dat vakkundige aktiwiteite - spesifiek studenteleer - verryk word deur diens aan die gemeenskap (HEQC 2006b:14-15).

Ten spyte van die verfynings en toepassings van 'n diensleerteorie, bly die model van David A. Kolb (1976; 1981; 1984) en sy kollega Roger Fry (Kolb en Fry 1975) 'n sentrale verwysingspunt vir bespreking. Deur voort te bou op die idees van Piaget, Dewey en Lewin (Lewin 1951), ondersoek Kolb en Fry (1975) die prosesse wat met diensleer geassosieer word. Hulle beskou diensleer as 'n strategie wat onderrig, persoonlike ontwikkeling en werk integreer (HEQC 2006a:17).

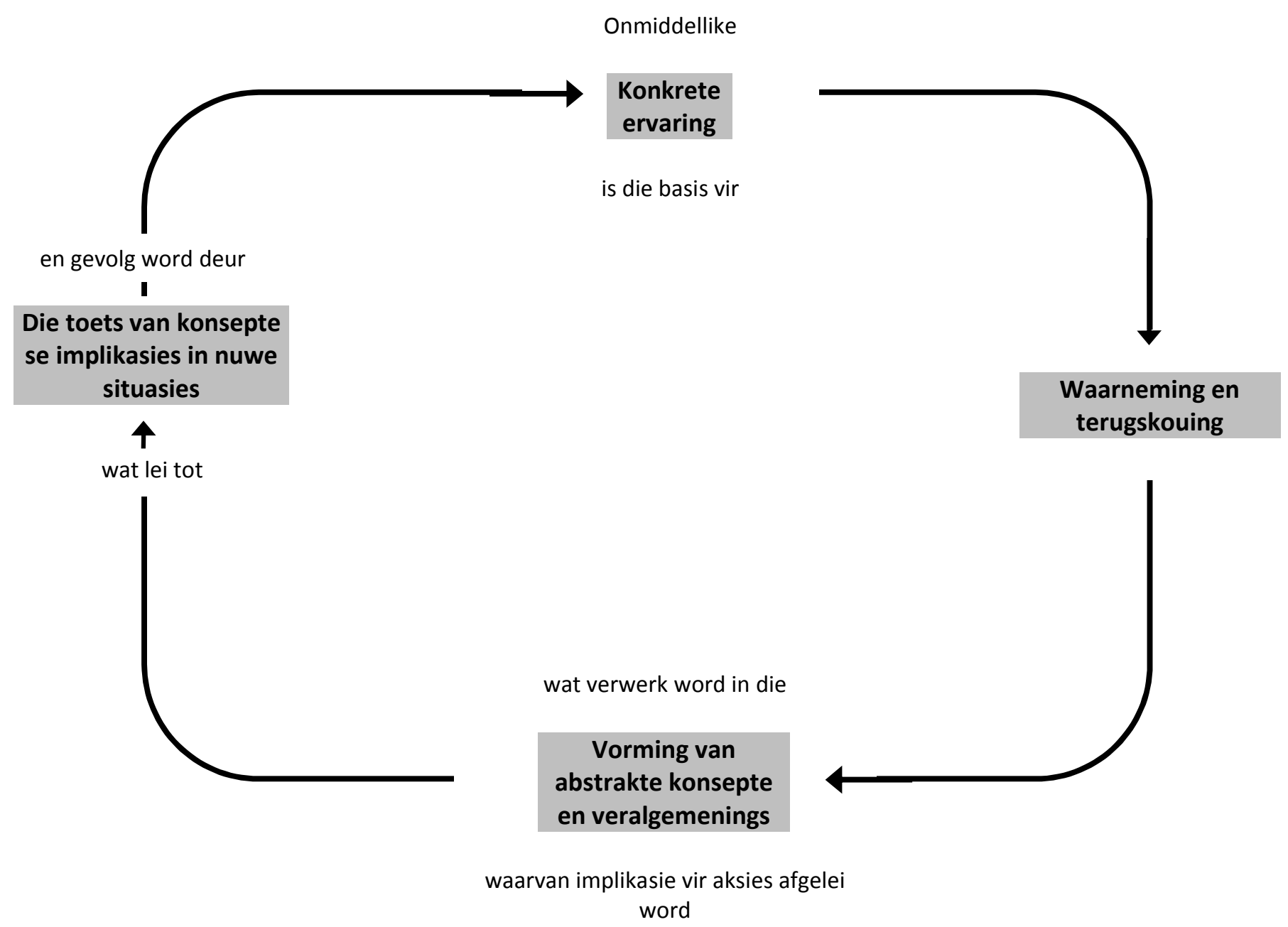

Figuur 2: Kolb (1984:41) se siklus van ervaringsleer

Die kritieke patroon van alle kennis wat uit ervaring verwerf word, deur terugskouing tot by konseptualisering en optrede, en terug na verdere ervaring, word deur Kolb se konsep van ervaringsleer (in die geval van die leerlingtolk) verder belig. Konkrete ervaring behels direkte praktiese ervaring. Witter-Merithew en Johnson (2005:45) bevind dat studente dieper vlakke 
van begrip bereik wanneer hulle saamwerk en oor hulle werk reflekteer. Terugskouing fokus op dit wat die diensleeraktiwiteit vir die individu beteken en verg waarneming, ondersoek, analise en interpretasie van ' $\mathrm{n}$ spesifieke konkrete ervaring. Abstrakte konseptualisering gee betekenis aan ontdekkings deur dit in verband te bring met ander ontdekkings en ander vorme van kennis. Deur middel van aktiewe eksperimentering word verdere optrede geneem en konseptualiserings (en die implikasies daarvan) in verskillende situasies getoets.

Navorsing het getoon dat diensleer 'n waardevolle pedagogiese hulpmiddel is wat gemotiveer word deur kundigheid wat verwerf moet word. Vir studente om maksimum baat te vind by die oefening, moet dit op so 'n wyse gestruktureer word dat dit studente-ontwikkeling bevorder. Hierdie siklus bied aan die student die vermoë om 'n skakel te skep tussen leerervaring, die teoretiese grondslag van hierdie ervaring en die reële wêreld. Verder bied hierdie siklus ook die raamwerk vir aktiewe eksperimentering wat konseptualisering kan transformeer, abstraksie in die praktyk kan toets en die volgende konkrete ervaring kan konstrueer en modifiseer. Volgens Sax en Astin (1997:25-33) is die uitkomste van diensleer gerig op akademiese ontwikkeling, lewensvaardighede - met inbegrip van rasseverdraagsaamheid - en kulturele insig (veral by interkulturele kommunikasie). Al hierdie aspekte is relevant vir die leerlingtolk.

Aangesien taal dikwels as vanselfsprekend aanvaar word, is dit belangrik dat daar op gemeenskapsinteraksies besluit word waar taalgebruik tydens die aktiwiteit onmisbaar is, en taal en wedersydse begrip ' $n$ impak op die gemeenskap het, maar bowenal dat die betrokke gemeenskap waarde heg aan die tolk se opleidingsdoelwitte. Die gemeenskap behoort betrokke te wees by die evaluering van die leerlingtolke. Dit kan egter problematies wees vir 'n hoogsgespesialiseerde aktiwiteit soos tolking. ${ }^{2}$ Die studente moet ook voortbou op hulle ervaring en dit is belangrik dat hulle dit deel met die res van die groep.

\section{Definisie van gemeenskapstolking vir internskappe}

Binne die konteks van gemeenskaps- of skakeltolking word gemeenskapstolking gedefinieer as 'n aktiwiteit wat kommunikasie fasiliteer tussen 'n openbare diensverskaffer en 'n gebruiker van daardie diens wat nie dieselfde taal deel nie (Lesch 1999a:116). Binne die Suid-Afrikaanse konteks word die term gemeenskapstolk omskryf as:

Someone who facilitates communication between a public service provider and a user of that service who do not share the same language or culture. Why are they called community interpreters? This is because their starting point is recognition that the problem of communication between these two parties is not simply a matter of language; it is equally created and compounded by the fact that they are separated by a wide gap of power. This power gap is directly related to class, race and/or culture, often gender and the differential power relations between a professional and his or her lay client. [...] Therefore the community interpreter is more proactive: he or she is not only the interpreter, who facilitates the communication requirements of these clients, but represents their interests,

\footnotetext{
${ }^{2}$ In 'n voorlopige peiling het ek agtergekom dat die gemeenskap wat talig oningelig is, die leerlingtolke veel hoër aanslaan wat hulle tolkvaardighede betref as diegene wat wel uit 'n taalagtergrond kom. Alhoewel taalgebruik 'n daaglikse aktiwiteit is, is tolking 'n geskoolde aktiwiteit en kan dit vir die oningeligte 'n probleem wees om tolkvaardighede te evalueer.
} 
assesses their needs and helps them to obtain whatever they are entitled to. (National Language Project (NLP) 1996)

Gemeenskap, soos gedefinieer in ooreenstemming met Lesch (1999b:92), is nie noodwendig 'n demografiese gemeenskap nie, maar eerder 'n groepering volgens die vlak van onderwys. Die ongelyke magsverhoudings en die voorspraakrol van die tolk is van die uiterste belang in hierdie definisie van die gemeenskapstolk.

Vir die doeleindes van hierdie artikel behels gemeenskap 'n sosiale groepering van die samelewing wat op enige gegewe oomblik in sosiale interaksie verkeer. Dit verwys na groepe mense wat saamgebind word deur 'n gemeenskaplike ligging, of na groepe mense wat intellektueel, professioneel en/of polities verbind is, d.w.s. enersyds geografiese gemeenskappe, en andersyds praktykgemeenskappe. Hierdie uitgebreide definisie laat ons toe om te fokus op gemarginaliseerde groeperings in die samelewing, terwyl ander gemeenskapsamestellings ook ingesluit word. Die prioriteit binne die konteks van hierdie artikel val op werklike talige interaksie met hierdie groeperings:

- Die aktiwiteit moet interaktief verbind word met 'n identifiseerbare groep in 'n gemeenskap.

- Interaksie moet aktief verbind word met identifiseerbare behoeftes van studente sowel as die gemeenskap. Wat betref leer en onderrig moet daar 'n duidelik geïdentifiseerde voordeel vir die gemeenskap en die student wees.

Die internskappe wat die studente binne 'n spesifieke gemeenskap doen (geografies, kampus, gesondheidsinstellings, op plase, ens.) word alles deur hierdie beskrywing van gemeenskap omvat, maar wat vir die leerlingtolk in hierdie geval relevant is, is die betrokkenheid by en blootstelling aan die groep om intertalige kommunikasie te fasiliteer met die hoofdoel om sy/haar tolkvaardighede deur diensleer in te oefen.

\section{Diensleer vir tolking}

Die komponent van diensleer vir tolkstudente behels dat hulle 'n tolkdiens in 'n gemeenskap (soos in die uitgebreide definisie hier bo gedefinieer) moet lewer. In 'n veeltalige land is daar op die oog af die aanvaarding dat toepaslike tolkgeleenthede geredelik gevind kan word, maar dit is makliker gesê as gedaan. In die Wes-Kaap is daar 'n groot behoefte aan skakeltolke op die gebied van gesondheidsorg (Levin 2005; Schlemmer 2005; Lesch 2007:74; Saulse 2010: 45). Volgens die genoemde kategorieë van diensleer is dit duidelik dat die gemeenskap (inbegrepe die professionele diensverskaffer en die kliënt) sowel as die leerlingtolk baat sal vind by die tolkdiens wat interkulturele kommunikasie fasiliteer. Tydens 'n ontmoeting met die uitvoerende komitee van een van die vernaamste akademiese hospitale wat verbind is aan die Universiteit Stellenbosch, Tygerberg Hospitaal, was almal dit eens oor die belangrikheid van gesondheidsorgtolking, maar steeds bly hulle in gebreke om die leerlingtolke toestemming tot toegang tot die instelling te gee. Die hoofbeswaar is etiese kwessies, waaronder die oordrag van verkeerde inligting deur die leerlingtolk en vertroulikheid van die pasiënt se inligting. Dit is geldige redes tot kommer, maar in 'n opname deur Feinauer en Lesch (2013:123) by dieselfde hospitaal, is bevind dat daar net een onopgeleide tolk vir hierdie groot instelling is. Die gaping tussen teorie en praktyk is ooglopend - om ten gunste van politieke korrektheid te argumenteer, maar die teenoorgestelde te doen. 
Om voorsiening te makk vir die etiese kwessies tydens internskappe, moet leerlingtolke die volgende vertroulikheidsklousule, soos gestipuleer deur die US, onderteken en nakom:

Hiervolgens onderneem ek om alle inligting waartoe ek toegang verkry en vergadering(s) wat ek tydens my indiensopleiding as tolkstudent sal bywoon, te alle tye streng vertroulik te hanteer. Indien ek my enigsins daaraan skuldig maak om hierdie inligting (mondeling en/of skriftelik) openbaar te maak, sal ek my skuldig maak aan oortreding en het die Universiteit Stellenbosch die reg om die nodige dissiplinêre stappe teen my in te stel met die reg om my ook strafregtelik te vervolg. (Universiteit Stellenbosch [2011a])

Dit is natuurlik debatteerbaar of hierdie dokument volgens wet bindend is en water sal hou in 'n hof. Tog bly dit 'n poging om studente ten minste bewus te maak van die beginsel van vertroulikheid van die inligting waartoe hulle toegang het. Dit bly ' $n$ uitdaging om binne 'n program van hierdie aard etiese kwessies te onderrig en te verseker dat studente dit wel in die praktyk nakom.

Die aanvanklike sessies vir die tolkinternskappe behels waarneming (luister ingesluit) van ervare tolke in aksie. As leerlingtolke moet die studente tydens hierdie waarnemingsessies onder andere waarneem hoe tolke hulle take in 'n professionele hoedanigheid verrig, en luister hoe hulle hulle weg vind met moeilike frases, of hoe hulle terminologie hanteer. In sommige gevalle het die professionele tolke nie die gerief of beskerming van 'n tolkkabine nie, maar omdat fluistertolking gebruik word, sit die tolke dus fisies in die vergaderings van aangesig tot aangesig met onder andere senior akademici. Aangesien hierdie sessies onder meer tydens senior vergaderings by die universiteit plaasvind, behels dit dat studente gekonfronteer word met verhoogvrees, en verg die situasie dat hulle emosioneel sterk moet wees sodat hulle nie verbouereerd raak indien iemand wat na hulle luister byvoorbeeld sy oorfone afhaal of as sy liggaamstaal aandui dat die tolk nie op peil is nie.

Binne 'n hospitaalkonteks sou verwag kon word dat 'n tolk emosioneel sterk behoort te wees weens die aard van boodskappe wat soms oorgedra moet word. Dit gebeur egter maklik dat die emosionele spanning rakende die buitetalige konteks waarmee leerlingtolke te doen kan kry, buite rekening gelaat word. (Sien die oorspronklike, ongeredigeerde uittreksel uit een student se internskapverslag in addendum C). Hieruit blyk dit dat benewens die etiese kwessie van vertroulikheid, die interkulturele aard van die aktiwiteit en haar onsekerheid oor die tolk se rol as raadgewer en vertrooster, die leerlingtolk ook gekonfronteer is met pyn, lyding en dood by die hospitaal waar sy haar internskap gedoen het. Dit is bykomend tot die rol wat tolke wel speel binne gesondheidsorg (Feinauer en Lesch 2013:121-122). In hierdie geval was die student wat dit ervaar het gelukkig 'n meer volwasse persoon, maar dit is beslis 'n aspek wat in gedagte gehou moet word. Hierdie emosionele ervaring kan direk verbind word met wat tydens die tolkmetodieksessies bespreek word met verwysing na een van die hooftemas, naamlik die rol van tolke tydens die Waarheid- en Versoeningskommissie (WVK). Om ander te leer oor die diskoers van die WVK wat volgens Anthonissen (2008:185) dikwels "emotionally charged and disputatious" was, of ander met inhoude "always highly charged [...] hearing of torture and death of (a) loved one", en om hierdie emosies tydens 'n tolksessie as tolk te ervaar, verskil hemelsbreed van mekaar. In so 'n geval ervaar die student eerstehands dat die tolk nie bloot 'n geleidingskanaal is waardeur woorde in een taal vir dié van 'n ander verruil word nie (Moreira 
2006). Dit is iets heeltemal anders om studente in die metodiek op te lei, as om hulle te begelei om emosioneel sterk te wees om ontstellende situasies te hanteer wat hulle innerlike krag tot die uiterste beproef.

Die tolkinternskap is gestruktureer in ooreenstemming met Bringle en Hatcher (1995:119) in die sin dat dit kredietdraend is. Daar word van studente vereis om hulle ervarings tydens die praktiese sessies - probleme, uitdagings, sowel as positiewe ervarings - met die res van die groep te deel. Die belangrikste is egter die geskrewe verslag wat van hulle verwag word teen die einde van die akademiese jaar. Addendum D behels 'n tweede oorspronklike, ongeredigeerde uittreksel uit so 'n verslag. Hierdie betrokke uittreksel beklemtoon vier belangrike aspekte van professionele tolkgedrag waarmee studente tydens internskappe te kampe kry en wat bydra tot die leerervaring. Eerstens leer hulle om hulp te verleen en dat hulle kan staatmaak op die hulp van 'n medetolk. 'n Verhouding ontwikkel tussen die leerlingtolke en dis maklik vir 'n student om met blote oogkontak hulp met 'n term te versoek, in plaas daarvan om uitdruklik daarvoor te vra. Terselfdertyd leer die passiewe tolk om tydens die hele sessie waaksaam te wees, al is hulle nie aktief besig om te tolk nie. Tweedens leer studente dat hulle nie bloot net kan tou opgooi nie, maar 'n professionele verantwoordelikheid het om 'n diens te lewer, en dat daar ' $n$ gehoor is wat na die boodskap luister. Dit beteken dat professionele optrede verwag word van studente. Verder ontwikkel studente selfvertroue deur die internskappe, en laastens leer studente om onder druk te werk. Behalwe dat tolke nie die luukse van tyd het nie, maar onmiddellik moet produseer, ervaar hulle ook die druk van die vergadering en moet hulle hul aanvanklike vrees oorkom.

Addendum E gee 'n opsomming van afleidings uit studenteverslae vir die jare 2005 - 2008. Altesame 23 studente verteenwoordigend van die tale Engels, Afrikaans en isiXhosa vorm deel van die korpus wat geanaliseer is. Benewens die verslag wat die studente voltooi, moet die leerlingtolke rekord hou van al hul tolkure. Verder word daar terugvoer verwag van die leerlingtolke en kort besprekings word op 'n gereelde basis gehou om hulle ervarings, probleme, uitdagings en vreugdes te deel.

\section{Die uitdagings van diensleer}

Binne die wetgewende en institusionele raamwerk, asook vanuit die perspektief van die tolkprogram self, is dit belangrik om die waarde van die internskappe te besef, en om vennootskappe met gemeenskappe te bevorder. Dit is belangrik om samewerkingsverhoudings te stig met verskillende gemeenskappe waar interkulturele kommunikasie ter sprake is en die betekenis van ' $n$ taalbemiddelaar binne die uitgebreide kommunikasieproses belangrik geag word. Hierdie vennootskappe het die potensiaal vir 'n oorkoepelende raamwerk en strategie vir gemeenskapsinteraksie en diensleer vir tolkopleiding. Daar moenie uit die oog verloor word dat internskappe die geleenthede verskaf om studentetolke deur die loop van die akademiese jaar aan 'n spesifieke aantal uur bloot te stel nie, en dat 'n betrokke leerlingtolk nie noodwendig by 'n spesifieke organisasie uitgeplaas word waar hierdie ure saamval nie. Dit maak die uitdagings (in ooreenstemming met HEQC 2006b:18-19) soos hieronder gelys, selfs nog uitdagender:

Wisselwerking: Om die verhouding tussen die tolkstudente (d.w.s. die tolkprogram) en die gemeenskap (sien weer bespreking onder 4) te bevorder, moet die verhouding wedersyds voordelig wees; dit beteken wisselwerking tussen dié wat bedien word, en dié wat leer uit die aktiwiteit. Dit is belangrik dat die tolkaktiwiteit dienslewering sowel as bepaalde leeruitkomste 
moet insluit. Die uitkomste wat bereik behoort te word met betrekking tot die gemeenskap (interkulturele kommunikasie) en dié met betrekking tot die studente, moet duidelik omskryf word. Vanuit die ervaring van die tolkprogram is laasgenoemde wel duidelik omskryf, terwyl eersgenoemde vaag is. In sommige gevalle is die diens wat gelewer word, bloot 'n simboliese gebaar.

Behoeftebepaling: Die kursus word gerig deur die behoeftes van die gemeenskap. Lesch (2005:16-17; 2007:74-76) beskryf die taalrealiteite in die Wes-Kaap en die behoefte aan tolke. 'n Goeie begrip van die taalwerklikheid is dus onontbeerlik vir die opleier, maar studente behoort ook op hoogte te wees van die taalwerklikhede van die gemeenskappe waarin hulle uitgeplaas word. Dit is belangrik dat die diensdoelwitte van die tolkprogram ooreenstem met die behoeftes wat deur die deelnemende gemeenskap gestel word. Hierdie assessering van die taalgemeenskap stel tolkstudente bekend aan navorsingsbeginsels wat nuttig te pas kan kom, sou die betrokke student verder nagraads studeer, en bied hulle ook die geleentheid om verhoudings met die taalgemeenskap te bou voordat hulle betrokke raak. Hoewel laasgenoemde 'n beginsel binne die konteks van gemeenskapsinteraksie is, maak die tydsbeperkings van die akademiese jaar dit bykans onmoontlik vir die betrokke studente, maar die kursuskoördineerder verleen in hierdie opsig die nodige kontinuitteit deurdat gepaste verhoudings in hierdie verband opgebou word. Die realiteit van die breër gemeenskap word in hooftrekke aangesny deur middel van verskillende temas wat tydens die module tolkmetodiek bespreek word. In ander gevalle is die studente vertroud met die taalsituasie.

Ooreenstemming van doelwitte: Om doeltreffende diensleer te waarborg, is dit baie belangrik dat diens- en leerdoelwitte gesinchroniseer word. Slegs wanneer dít die geval is, kan dienslewering 'n bydrae lewer tot kennisverwerwing, en insgelyks kan kennisverwerwing dienslewering verbeter.

Plasing van studente: Die vrae wat hier ter sprake is, is onder andere of studenteplasing geskik is vir die verlangde diens- en leeruitkomste; of daar voldoende en toepaslike toesig gehou word oor die leerlingtolke; of dié wat verantwoordelik is om toesig te hou oor die leerlingtolke voldoende voorberei is en of die leerlingtolke die nodige erkenning kry. Die plasing van tolkstudente is ' $n$ uitdaging, veral ook in die lig daarvan dat die studente aan verskillende tolkmodusse en -genres blootgestel behoort te word, maar dit nie altyd haalbaar is nie. Afrikataaltolke word meer benodig in hospitale (d.i. konsekutiewe of skakeltolking), terwyl daar op die kampus van die US 'n groter behoefte bestaan aan Afrikaanse en Engelse tolke vir fluistertolking (simultaan). Hoewel moderne vreemde tale (Duits, Nederlands, Frans, Mandaryns) in samewerking met kollegas van die betrokke departemente, wel in die kursus geakkommodeer kan word, is die bepaalde taalkombinasies vir tolkinternskappe binne die onmiddellike omgewing uiters beperk.

Reisafstande: Die afstand wat in sommige gevalle afgelê word, is 'n verdere praktiese probleem vir studente se tolkinternskappe. Dit is ongemaklik vir studente, veral omdat hulle nie vir 'n vasgestelde tydperk by 'n spesifieke instansie uitgeplaas word nie, terwyl dit wel vir die vertaalinternskappe gereël word. In sommige gevalle verg dit fyn beplanning om te verhoed dat die reistyd met hulle lesings bots.

Studente-oriëntering: Studente moet genoegsaam voorbereid wees vir hulle internskappe sodat hulle weet wat hulle kan verwag van die tolksessie of die plek waar hulle uitgeplaas word. Die 
idee van die waarnemingsessie is juis om die studente te oriënteer t.o.v. die beroep, die werksomgewing en hulle internskappe, maar vir studente om toegang daartoe te verkry, is ook 'n burokratiese oefening. Vertroulikheid van inligting, sowel as etiese kwessies rakende die inligting waartoe hulle toegang het, is steeds rede tot kommer.

Verduideliking van rolle: Die rolle en verantwoordelikhede van alle deelnemers moet duidelik en noukeurig uitgespel word vir alle betrokkenes. Daar moet geen onduidelikheid wees oor die diens wat die studente lewer of oor die kapasiteit van leerlingtolke nie. So byvoorbeeld sal tolke se rol binne 'n gesondheidsorginstelling verskil van dié binne die universiteitsgemeenskap. In die een geval sal die tolke onder meer blootgestel word aan 'n voorspraakrol wat hulle moet vertolk, terwyl dit nie in ander gevalle verwag word nie.

Indompeling: In sommige gevalle doen die geleentheid vir ' $\mathrm{n}$ tolksessie dit voor knap nadat die kursus begin het. Met weinig kennis en blootstelling - teoreties sowel as prakties - word die studente dus in die internskapsessie gedompel, en raak dit 'n geval van tolk of sink. Dit is beslis nie ideaal nie, maar omdat die geleenthede so beperk en ongereeld is, word dié vroeë geleenthede aangegryp.

Terugskouing: Voldoende tyd moet beskikbaar gestel word vir gestruktureerde en kritiese refleksie oor die ervaring, sowel as vir integrasie van metodiek en teorie wat tydens die verloop van die kursus aangebied word. Gestruktureerde terugskouing is 'n basiese en noodsaaklike onderdeel van enige kursus wat diensleer insluit. Dit is deur kritiese terugskouing dat diensleer en teorie mekaar aanvul.

Logistiek: 'n Groot uitdaging is dat behoorlike en doeltreffende logistiese reëlings getref moet word met inagneming van studente se roosters, vervoer, veiligheid, ens. Die uitplasing van studente op ' $n$ ad hoc-basis gedurende die akademiese jaar verg uitgebreide en deurlopende logistiese reëlings. 'n Verdere logistiese oefening is die skep van verdere geleenthede (bv. tolking tydens lesings) om die kwota internskapure aan te vul.

Taalkombinasies: Die onmiddellike konteks maak voldoende voorsiening vir Afrikaans en Engels, maar is beperkend vir tolkgeleenthede in Afrikatale. In ander gevalle bied moderne vreemde tale ook ' $n$ uitdaging vir sover dit uitplasing vir diensleer betref. Die reisafstand na die middestad is 'n probleem, en taalkombinasies en tolkgeleenthede bly beperk.

Vennootskappe: Die vennootskappe wat gevorm word, is in sommige gevalle gebaseer op betaling - die praktykgemeenskap betaal 'n minimum bedrag vir die tolkdiens. Die befondsing word teruggeploeg in die program, maar hierdie betaling skep die moontlikheid vir probleme, aangesien die teikenmark gevolglik meer krities ingestel is teenoor die diens. Juis vanweë die "betaling" vir die diens vervaag die hele gedagte van vennootskap en wisselwerking. In 'n beperkte aantal gevalle werk leerlingtolke saam met 'n onopgeleide tolk wat drie tale magtig is en wat 'n permanente pos as tolk beklee, maar minder besorg is oor professionele etiket. Natuurlik stel dit nie 'n goeie voorbeeld vir die leerlingtolk wat ingeskryf is vir 'n nagraadse kursus om as professionele tolk te kwalifiseer nie.

Evaluering: Gehalteversekering vir gemeenskapsinteraksie, en dus ook vir die diensleer wat daarmee gepaardgaan, behels dat die gemeenskap by die evaluering van die diens betrek word. Omdat dit taalgebruik is wat ter sprake kom by tolking, is daar die geneigdheid om te dink dat 
dit bloot taal is wat geëvalueer behoort te word en dat geen spesiale kundigheid vereis word nie. In 'n opname oor die diens is bevind dat die leek neig om té vrygewig teenoor die leerlingtolke te wees, terwyl die taalpraktisyn wat tekortkominge in die student se tolking kan identifiseer, krities is. Dit wil voorkom of die beoordelaars van die teikenmark ook geskool behoort te word t.o.v. die gehalte van diens en waarop gelet behoort te word.

Die belangrikheid van diensleeraktiwiteit vir leerlingtolke behoort geensins in twyfel getrek te word nie. Die studente doen eerstehandse ervaring op en kom in die proses agter dat hulle meer as slegs 'n kanaal is waardeur die boodskap van die brontaal na die doeltaal oorgedra word. Binne die konteks van die program en die beleidsraamwerk wat geld, kan tolking 'n belangrike medium wees vir gemeenskapsinteraksie, maar ongelukkig is dit nie sonder uitdagings nie.

Hierdie vorm van gemeenskapsinteraksie en die gepaargaande uitdagings wat dit bied, kan egter ook vir die leerlingtolk rampspoedig wees. Daar kan nie nagelaat word om te verwys na 'n insident waarby twee leerlingtolke betrokke was en wat die plaaslike koerant, Die Burger, gehaal het nie (sien addendum A). Die artikel begin met die volgende sin, wat die leerlingtolke in 'n uiters negatiewe lig plaas: "Gebrekkige tolkdienste by 'n debat oor die Universiteit Stellenbosch (US) se taalbeleid het daartoe gelei dat die debat ontspoor het toe andertalige studente 'n Afrikaanse spreker 'n ruk stil geskree het'. Soos dit hier gestel word, is dit beslis 'n refleksie op die gehalte van die tolkdiens. Eers wanneer die leser verder lees, besef 'n mens dat die ware probleem onstaan het as gevolg van die tekort aan oorfone: "'n Tekort aan oorfone vir nie-Afrikaanssprekende studente om die verrigtinge te kon volg, was oënskynlik 'n groot ergernis." Om te vergoed vir die tekort aan oorfone, is dieselfde tolk versoek om oor te skakel na die konsekutiewe modus. Die koerantartikel vervolg met: "'n Tolk [dit was dieselfde tolk wat toe konsekutief moes tolk - HML] se hulp is toe ingeroep, maar sy kon nie die mas opkom nie."

Wat duidelik hieruit blyk, is dat die teikenmark, sowel as die joernalis ingelig behoort te word (verkieslik vooraf) oor die kapasitiet van die tolke en hulle rol - veral in die geval van leerlingtolke. Hierdie insident het gelei tot die verklaring wat voor elke vergadering waar leerlingtolke diens doen, duidelik vertoon of hardop gelees word as 'n manier om die leerlingtolke te beskerm (sien addendum B) (Universiteit Stellenbosch (2011b). Die doel van die verklaring is om direkte onredelike kritiek teenoor leerlingtolke deur individuele afgevaardigdes tydens die vergadering te voorkom, aangesien dit negatiewe gevolge vir die tolke kan inhou. Probleme moet liewer onder die aandag van die dienskoördineerder gebring word. Boonop kan die betaling ook 'n bydraende faktor wees, aangesien die tarief wat gehef word, sekere verwagtinge skep by die leek. Die betaling is egter minimaal en is eerder 'n gebaar van waardering vir die diens wat gelewer word. Gevolglik kan spanning onstaan as gevolg van die betaling en die dienslewering. Verder moet daar nie uit die oog verloor word dat taal 'n aktuele kwessie is by die betrokke instelling waar hierdie insident plaasgevind het nie, en dat daar moontlik ook verskuilde motiewe opgesluit kon wees in die plasing van die betrokke artikel.

\section{Slotopmerkings}

Die verwerwing van kennis deur ervaring is 'n belangrike aspek van opleiding vir tolke. Soos vermeld in die inleiding, behoort aktiwiteite van diensleer nie lukraak te geskied nie, maar opleiers en mentors moet begrip hê vir die leersiklus en vir die wyse waarop elke stap werk, 
om sodoende studente en protégés deur die leerproses te help. Op hierdie wyse sal die leerling voorsien word van "a rich learning experience and an avenue [...] to achieve life-long skills refinement” (Bentley-Sassaman 2009:67).

Baie tolke se verwerwing van kennis en vaardigheid vind aan diens plaas - dus deur middel van ervaring. Vir tolkstudente geskied dit tydens hulle praktiese werk wanneer hulle deur ervaring leer onder die toesig van 'n mentortolk (Witter-Merithew en Johnson 2005). Afgesien van die bestaande uitdagings, moet opleiers probeer om vennootskappe vir diensleer, sowel as geleenthede vir hulle studente te ontwikkel sodat studente eerstehands meer oor hulle toekomstige beroep te wete kan kom. Die diensleerteorie neem die student deur 'n siklus van vier leervaardighede. Hierdie teorie en die vier leervaardighede van die siklus hou direk verband met hoe tolkstudente leer namate hulle deur hulle lesings vorder. Dit stel die leerlingtolk ook bloot aan toepaslike vaardighede ten opsigte van verskillende relevante modelle (bv. voorspraak- of begeleiers-, toevoegings- en byvoegingsmodel) en is veel meer ontwikkeld as die verouderde meester-en-vakleerlingskapmodel. Vanuit die perspektief van die opleier verskaf hierdie diensleersiklus ook die geleentheid en impetus vir gepaste kurrikulumontwikkeling.

\section{Bronnelys}

Anthonissen, C. 2008. On Interpreting the Interpreter - Experiences of Language Practitioners in Mediating for the TRC. Journal of Multicultural Discourses 3(3): 165-188.

Bentley-Sassaman, J. 2009. The Experiential Learning Theory and Interpreter Education. International Journal of Interpreter Education, Conference of Interpreter Trainer: 60-67.

Boyer, E. L. 1990. Scholarship Reconsidered. San Francisco: The Carnegie Foundation for the Advancement of Teaching.

Bringle, R.G. en J.A. Hatcher.1995. A Service-learning Curriculum for Faculty. Michigan Journal for Higher Education 2:1: 112-122.

Die Burger, 2009. Debat oor Taal by US ontspoor. 8 Mei.

Feinauer, I. en H.M. Lesch. 2013. Health workers: idealistic expectations versus interpreters' competence. Perspectives: Studies in Translatology 21(1): 117-132.

Furco, A. 1996. Service Learning: A Balanced Approach to Experiential Education. In B. Taylor (red.). Expanding Boundaries: Serving and learning. Washington DC: Learn and Serve America. 2-6.

Gile, D. 1995. Basic Concepts and Models for Interpreter and Translator Training. Amsterdam: John Benjamins.

HEQC. 2006a. Service Learning in the Curriculum, a Source for Higher Education Institutions. Pretoria: JET Education Services, Council on Higher Education. 
HEQC. 2006b. A Good Practice Guide and Self-evaluation Instruments for managing the Quality of Service Learning. Pretoria: JET Education Services, Council on Higher Education.

Hoover, J. D. en C. Whitehead 1975. An Experiential-Cognitive Methodology in the First Course. In R.H. Buskirk (red.). Management: Some Preliminary Results, Simulation Games and Experiential Learning in Action. 25-30.

Kolb, D.A. 1976. The Learning Inventory: Technical Manual. Boston: McBer en Co.

Kolb, D.A. 1981. Learning Styles and Disciplinary Difference. In Arthur W. Chickering (red.) The Modern American College. San Francisco: Jossey-Bass. 233-255.

Kolb, D.A. 1984. Experiential Learning. Experience as the Source of Learning and Development. Englewood Cliffs: Prentice Hall.

Kolb, D.A. en R.E. Fry. 1975. Towards an Applied Theory of Experiential Learning. In C. Cooper (red.). Theories of Group Processes. Londen: Wiley. 33-58.

Lesch, H.M. 1999a. Gemeenskapsvertaling in Suid-Afrika: die konteks van die ontvanger as normeringsbeginsel. Ongepubliseerde doktorale proefskrif. Universiteit van Wes-Kaapland, Bellville, Suid-Afrika.

Lesch, H.M. 1999b. Community Translation: Right or Privilege? In M.Erasmus, L.Mathibela, E Hertog en H. Antonissen (reds.). Liaison Interpreting in the Community. Hatfield: Van Schaik. 90-98.

Lesch, H.M. 2004. Societal Factors and Translation Practice. Perspectives: Studies in Translatology 12: 4: 256-269.

Lesch, H.M. 2005. The Scope of Language Services in an Emerging Multilingual Country. Translating Today 3: 16-19.

Lesch, H.M. 2007. Intelligibility by Means of Plain Language for Interpreting. Curationis 30: 4: 73-78.

Levin, M. 2005. The Importance of Language and Culture in a Paediatric Asthma Care. Current Allergy \& Clinical Immunology 18: 1: 8-12.

Lewin, K. 1951. Field Theory in Social Science: Selected Theoretical Papers. New York: Harper and Row.

Moreira, C. 2006. An Invisible Traitor. In http://www.kwintessential.co.uk/translation/articles text-translator.html (Maart 2013).

National Language Project, 1996. Information Sheet,Soutrivier.

Saulse, B. 2010. Interpreting within the Western Cape Health Care Sector: a Descriptive Overview. Ongepubliseerde M-tesis, Universiteit Stellenbosch. 
Sawyer, D.B. 2006. Interpreter Training in Less Frequently Taught Language Combinations: Models, Materials, and Methods. In C.B. Roy (red.). New Approaches to Interpreter Education. Washington DC: Gallaudet University Press. 105-124.

Sax, L.J. en A.W. Astin. 1997. The Benefits of Service: Evidence from Undergraduates. Educational Record 1997: 78, 25-33.

Schlemmer, A.C. 2005. Exploring the Effects of a Language Barrier Between the Patients and Staff at Hottentots Holland Hospital. Ongepubliseerde MFamMed.-tesis. Universiteit Stellenbosch, Suid-Afrika.

Universiteit Stellenbosch. 2011a. Vertroulikheidsverklaring soos van toepassing op leerlingtolke.

Universiteit Stellenbosch. 2011b. Dokument oor tolkdienste wat tydens elke vergadering vertoon moet word waar leerlingtolke diens doen.

Winston, E. A. 2005. Designing a Curriculum for American Sign Language/English Interpreting Educators. In M. Marschark, R. Peterson en E.A. Winston (reds.). Interpreting and Interpreting Education: Directions for Research and Practice. New York: Oxford University Press. 208-234.

Witter-Merithew, A. en L. J. Johnson. 2005. Toward Competent Practice: Conversations with Stakeholders. Alexandria: Registry of Interpreters for the Deaf Press. 


\section{Addendum A}

\section{Debat oor taal by US ontspoor}

Stellenbosch - Gebrekkige tolkdienste by 'n debat oor die Universiteit Stellenbosch (US) se taalbeleid het daartoe gelei dat die debat ontspoor het toe andertalige studente' $n$ Afrikaanse spreker' $n$ ruk stil geskree het. Vroeër die aand is sprekers egter ongehinderd toegelaat om hul toesprake in Engels te voltooi.

Talle Maties het Woensdagaand in die ouditorium van die J.S. Gericke-biblioteek aan die debat oor diversiteit en die US se taalbeleid bygewoon. 'n Tekort aan oorfone vir nie-Afrikaanssprekende studente om die verrigtinge te kon volg, was oënskynlik 'n groot ergernis.

Die debat was deel van die Tweede Nuwe Hoop-studenteberaad wat deur die US se studenteraad, studentesake en die Adam Tas-studentevereniging gereël is.

Die eerste spreker, mnr. Mohamed Shaikh, kommunikasiehoof van die US, het die studente in Afrikaans en Engels toegespreek oor sy eie ervaring van die taalbeleid en nie vanuit ' $n$ USbestuurstandpunt nie.

Die US moes hom ná die 1994-verkiesing in 'n groter politieke konteks herdefinieer. "Die US is ' $n$ nasionale instelling en is oop vir enigiemand wat vir toelating kwalifiseer, ongeag sy of haar ras," het Shaikh gesê.

Mnr. Tshepo Mvulane, 'n magisterstudent in internasionale studie, het sy hele toespraak in Engels gehou. Geen student het daarteen beswaar gemaak nie. Mvulane het gesê Afrikaans as taal is nie die probleem by die US nie, maar wel die hele kulturele pakkie wat daarmee verbind word.

Mnr. Piet le Roux, 'n oud-Matie en laaste spreker van die aand, het in Afrikaans met Mvulane se standpunt saamgestem. Sy toespraak is egter kortgeknip deur nie-Afrikaanssprekende studente. Hulle het nog oorfone vir die tolkdiens versoek, maar daar is nie genoeg vir die aand bestel nie.

Anderstalige studente het toe daarop aangedring dat Le Roux sy toespraak in Engels moet lewer, maar hy het geweier. "Ek het my toespraak in Afrikaans voorberei, nie in Engels nie. Die boodskap wat ek wil oordra, sal nie dieselfde effek hê nie," het hy verduidelik. Hierop is hy stil geskree.

'n Tolk se hulp is toe ingeroep, maar sy kon nie die mas opkom nie. Le Roux het sonder ' $\mathrm{n}$ tolk in Afrikaans voortgegaan en sy toespraak verkort.

'n Student het in Engels opgemerk: “Hierdie is ' $n$ grap. Wat is die punt om ' $n$ gesprek te voer as ons dit nie kan verstaan nie?" 


\section{Addendum B}

\section{$\underline{\text { Rakende die tolkdiens }}$}

Tolke is professionele individue wat spesiaal opgelei word om hierdie uiters uitdagende taak te verrig. Aan die US is dit weliswaar ' $n$ nagraadse kursus met streng toelatingsvereistes. Omdat nie alle instellings professionele tolke kan bekostig nie, en u instelling het besluit om van leerlingtolke gebruik gemaak. Hierdie tolke is nog in opleiding en ons dienste kos derhalwe ' $n$ breukdeel van dié van professionele tolke, maar hulle lewer'n baie belangrike diens en help mee om die taalsituasie op kampus te fasiliteer.

Om enige misverstand oor die tolke te voorkom en om onbillike kritiek te vermy, versoek ons gevolglik dat $u$ die volgende punte telkens baie duidelik onder die aandag van $u$ vergadering sal bring:

- Die tolke wat gebruik word, is nog in opleiding en nie professioneelgekwalifiseer nie;

- Die tolke word voorsien as deel van hulle internskappe en kry dus geen betaling vir hulle werk nie;

- Die tarief (indien enigsins) wat gevra word, is vir administratiewe en bedryfskoste en is nie naastenby vergelykbaar met dié van professionele tolke nie;

- Indien daar enige kommentaar op die tolkdiens is, moet dit aan die bestuur van u instelling gekommunikeer word, wat dit dan aan die koördineerder van die tolkprogram sal oordra, en nie direk deur individuele lede nie.

Ons vertrou op u samewerking in hierdie verband.

Vriendelike groete

DEPARTEMENT AFRIKAANS EN NEDERLANDS - DEPARTMENT OF AFRIKAANS AND DUTCH

PRIVAAT SAK/PRIVATE BAG X1 • MATIELAND 7602 • SUID-AFRIKA/SOUTH AFRICA

TEL: +27 $218082158 \cdot$ FAKS/FAX: +27 218083815 


\section{Addendum C}

The arrangement took place telephonically and [...] he told me that I will not be interpreting in the wards because of the fact that some patients' illnesses are to be kept in confidentiality. I was placed at Casualty. I must mention that this is a public hospital which has its diversity. It is diverse in the sense that patients are three different races. There are Black, White and Coloured patients that depend on the services of this hospital.

I had to face my biggest fear in life. There was an old man who was very sick. His family was there with him. This man was so sick; I could not understand why they kept him at Casualty and not in the wards. I just have to sit and wonder; I was not there to interfere with the state of affairs of the hospital. It is with great sadness to report that I saw that old man dying and the family mourning his departure. This is what I feared most since I my childhood. I never thought I would be able to witness an end of life.

I was also hurt when I saw a young boy, who apparently had broken his leg, was sitting there crying because he was in pain. He was being taken for X-rays and the nurse in charge of him was busy chatting with a colleague. The nurse kept on telling the boy that he was making a noise and must keep quiet. I again could not interfere because I was there just to interpret. 


\section{Addendum D}

The main problem during interpreting was the choice between certain terms when there were a variety offered and the university does indeed prefer to use one term above the other for various reasons. Another problem was the pace at which the speakers spoke, especially when they were among the audience and roving microphones were not available. In the instance where the speaker standing in the front [with their backs facing the interpreters - HML] posed difficulty in his speech pace, one was able to deduce what he was saying based on the overhead slides that were shown. Another problem was that we became too dependent on the agenda thinking that the meeting would follow its structure completely, while it diverted from it. In some cases after a question was posed to the speaker and an answer involving different terms that were not indicated on the agenda, was relayed.

Our initial act when a problem occurred was always to look at the fellow interpreter in search of their assistance; by writing the word we missed on a piece of paper. If this attempt proved to be futile we would simply pass the microphone over to the fellow interpreter to continue. The first session and after gaining more theoretical knowledge into the interpreting profession through our theory lessons, I was able to move on after a word or phrase was missed or not understood and tried to conceptualise the speech as far as possible to the best of my ability.

On the whole, the programme enabled me to experience the various challenges within the interpreting world ... Furthermore, when one is in a moment of extreme concentration while interpreting simultaneously, a technical problem or loss in thought span could occur. There is no fixed solution to this problem; every interpreter has his/her own way of dealing with problems arising in the booth. One cannot simply stop and give up when an audience is watching and waiting on you to relay the message unto them.

After the first session, I started to become more confident while interpreting, being more sure of myself and that I was able to relay a message which the target language listener could interpret within the context of the meeting. The session that was held with the SRC, was definitely the more relaxed session. One could be more positive that the listeners could not deduct a (sic) error on the interpreter's side as easily.

My most recent session at the Tygerberg campus staff meeting with the rector, definitely proved to me that I was able to perform under pressure at first and then calmly ease into the action and do what is expected of me more confidently.

Overall, the practice sessions proved to be of great assistance during my interpreting course. Not only did the course offer me an opportunity to learn and grasp various concepts pertaining to the interpreting environment, but it also offered guidance and support which made the programme an even more fruitful experience. 


\begin{tabular}{|c|c|c|c|}
\hline 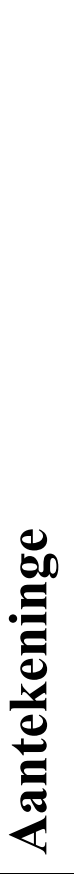 & 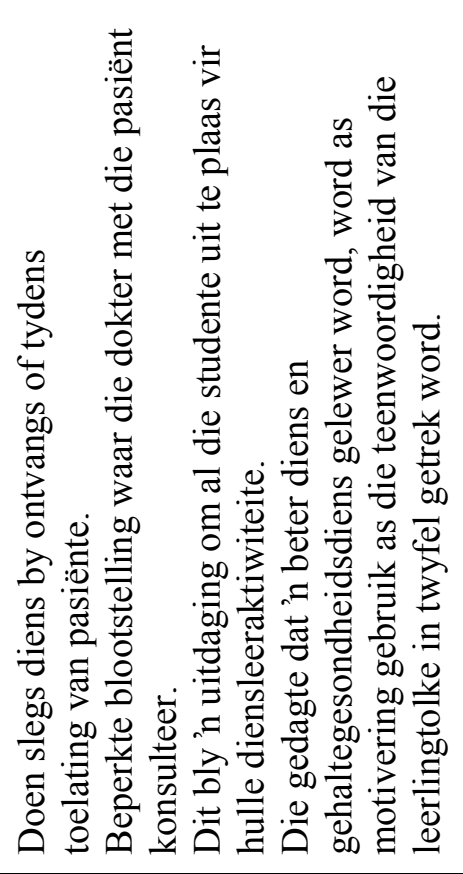 & 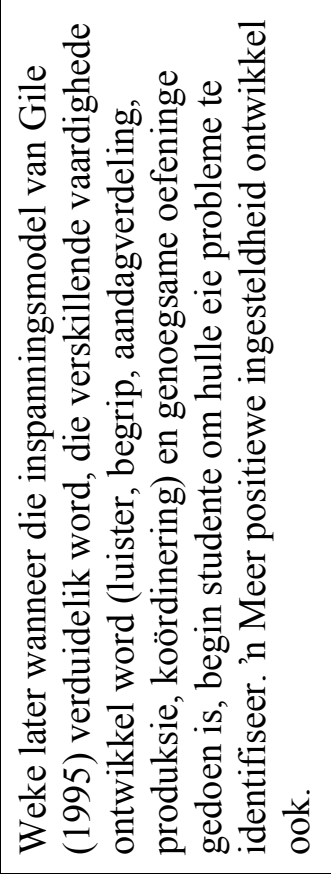 & 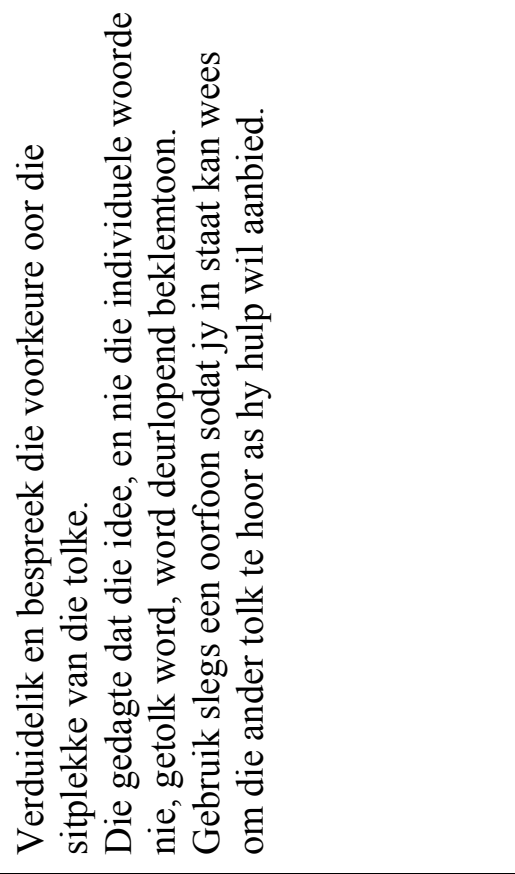 \\
\hline 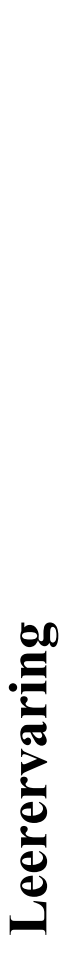 & 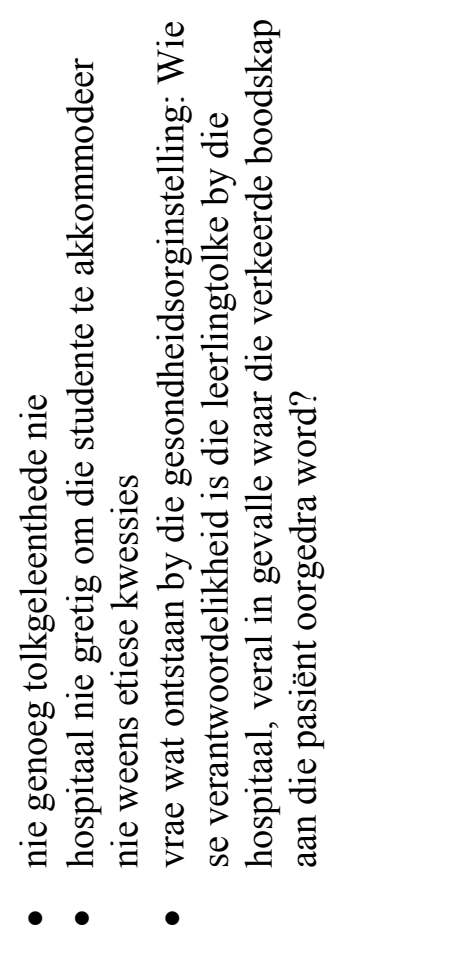 & 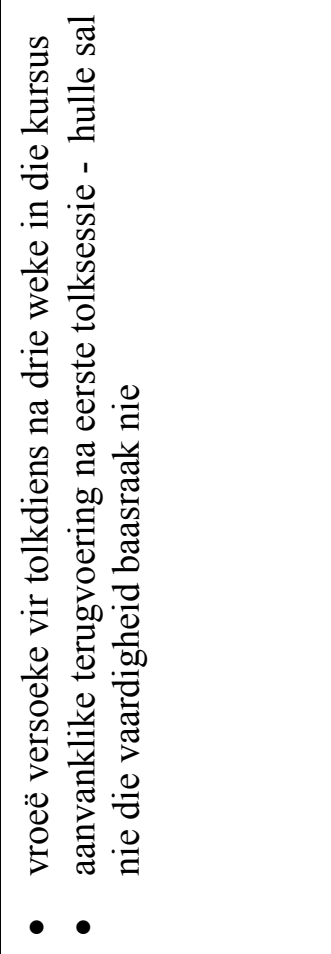 & 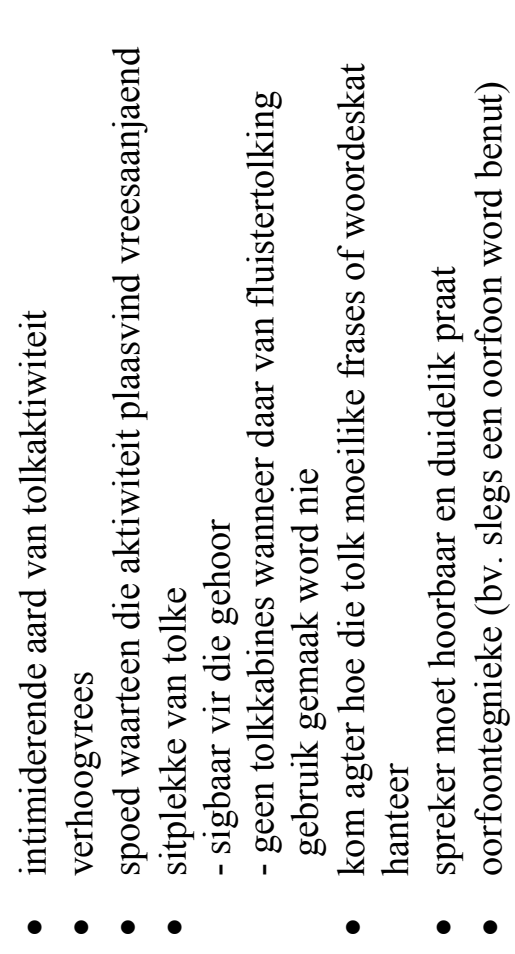 \\
\hline 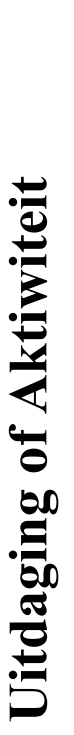 & 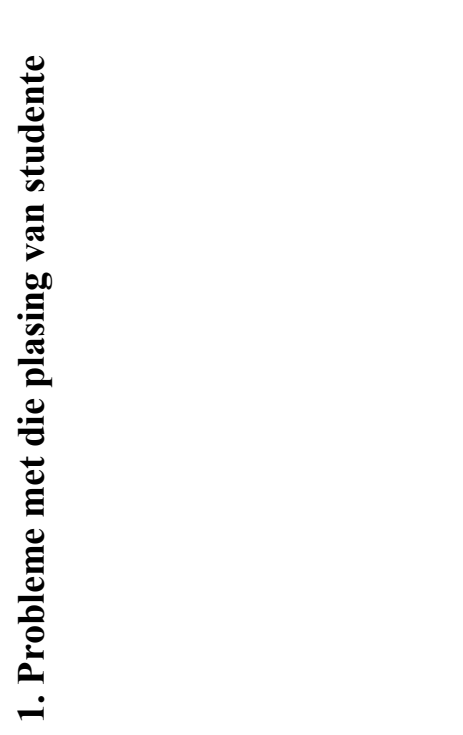 & 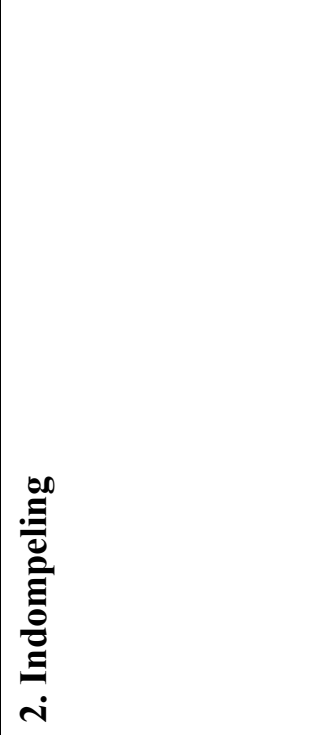 & 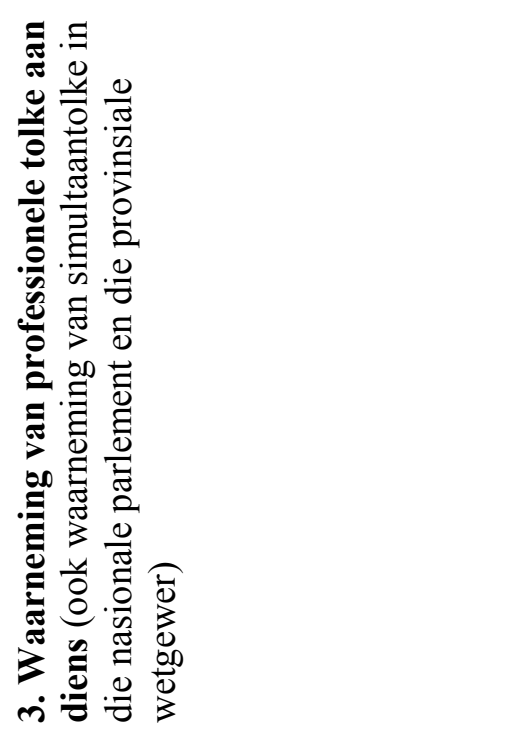 \\
\hline
\end{tabular}




\begin{tabular}{|c|c|c|c|}
\hline & 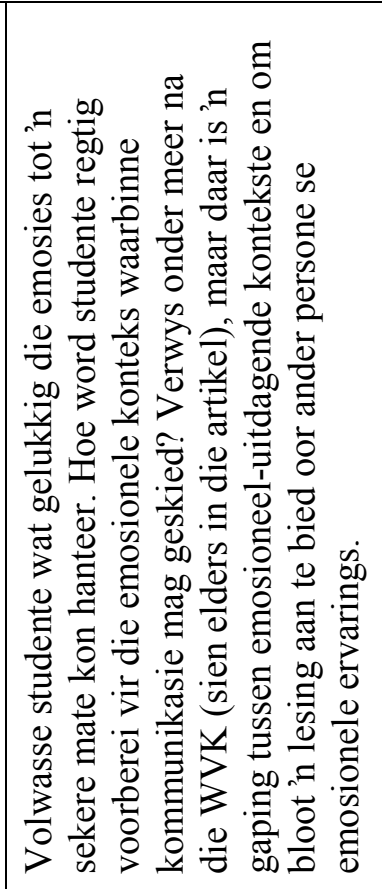 & 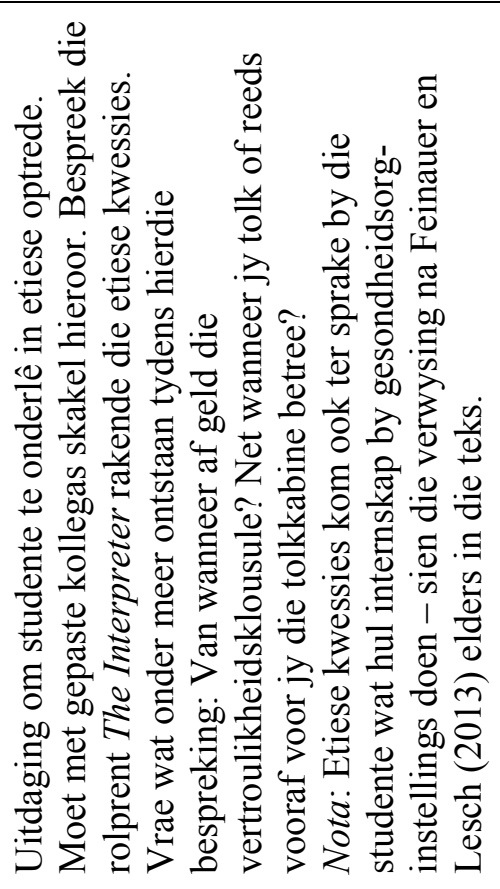 & 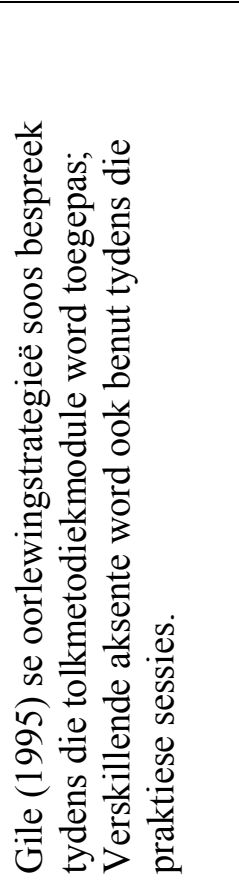 \\
\hline 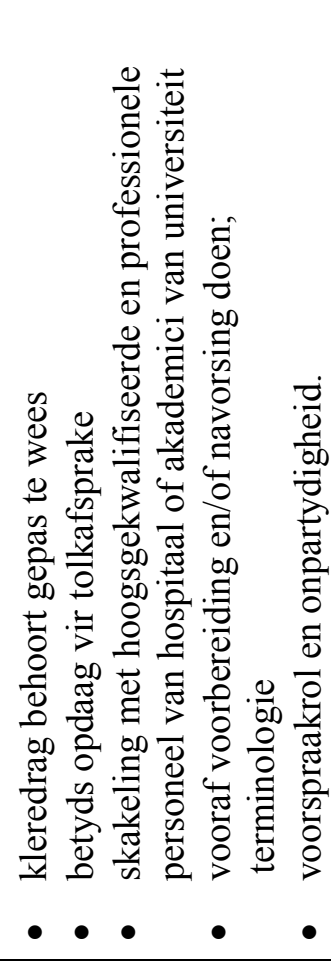 & 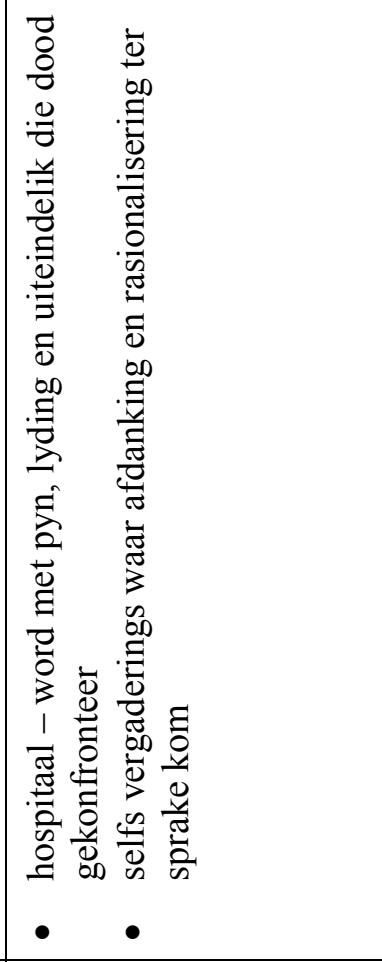 & 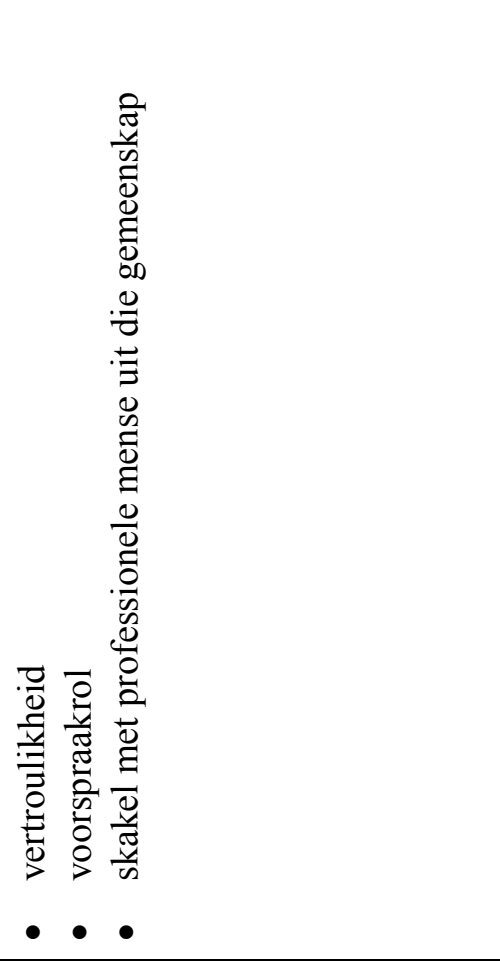 & 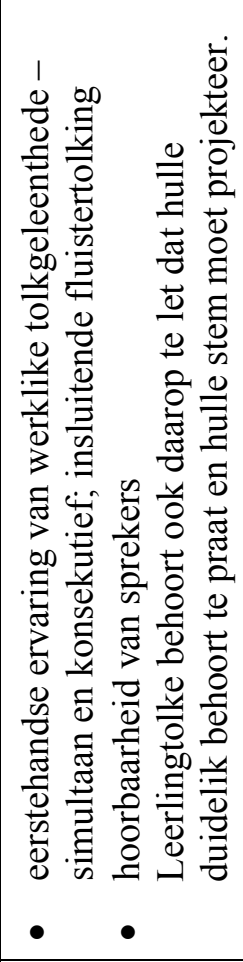 \\
\hline 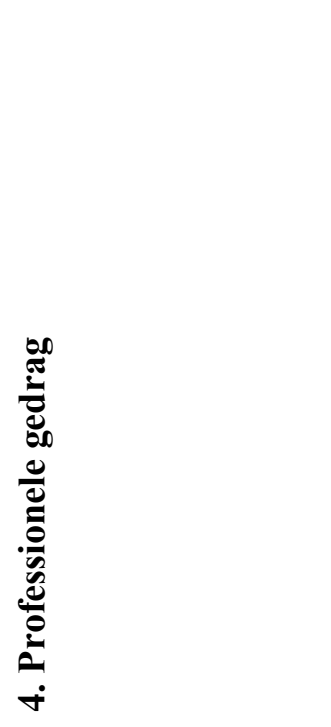 & 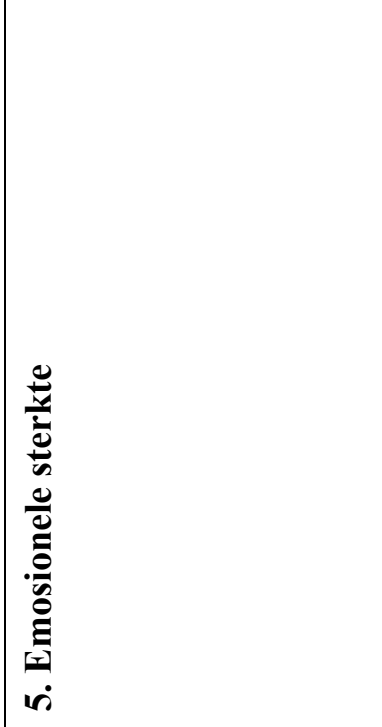 & 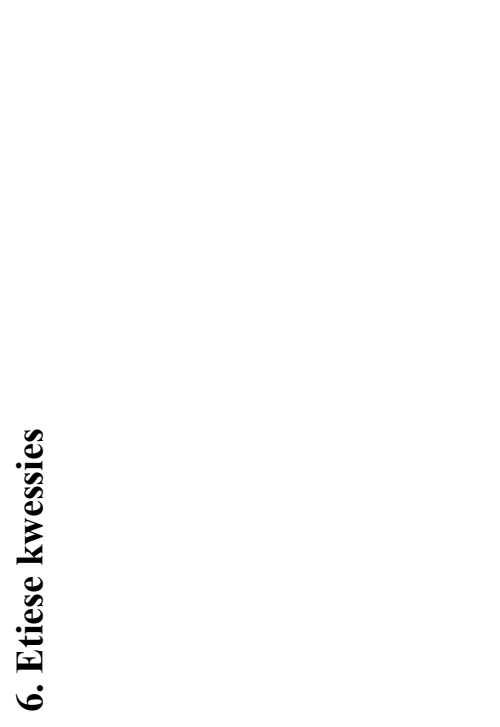 & 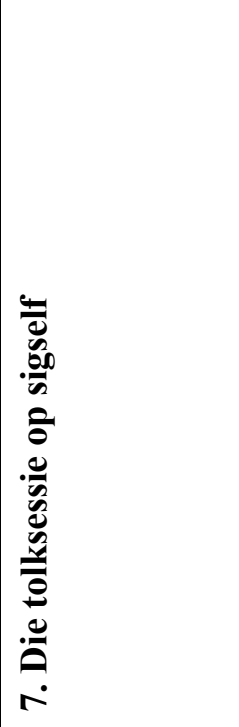 \\
\hline
\end{tabular}




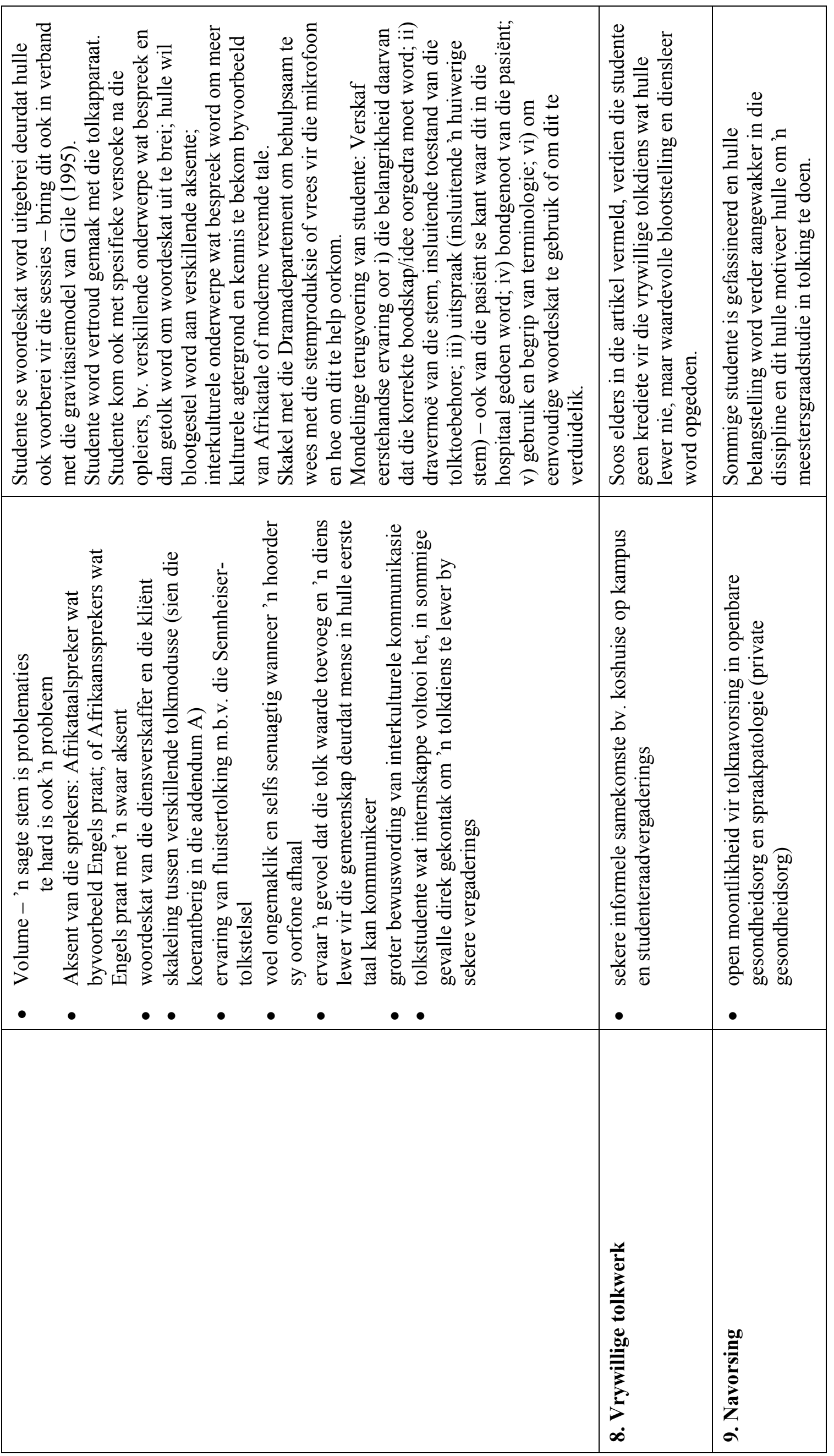

